\title{
Utilization of Solid Palm Oil Waste Compost (Sludge) and NPK Fertilizer in Increasing Spring Maize (Zea mays L.) Growth and Yield
}

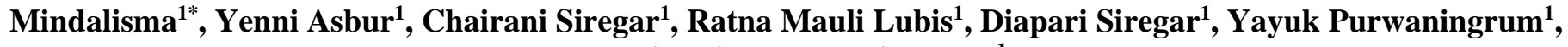 \\ Rahmi Dwi Handayani Rambe ${ }^{1}$
}

${ }^{1}$ Department of Agrotechnology, Faculty of Agriculture, Universitas Islam Sumatera Utara, Jalan Karya Wisata Gedung Johor, Medan 20144,

DOI: 10.29322/IJSRP.12.01.2022.p12147

http://dx.doi.org/10.29322/IJSRP.12.01.2022.p12147

\begin{abstract}
Spring maize is maize cobs that are harvested at a young stage as a vegetable ingredient. Therefore, the initiative and commercial cultivation of spring maize with an agribusiness pattern has bright prospects This study aims to determine the effect of compost sludge and NPK fertilizer on the growth and yield of spring maize. The research method used a factorial randomized design with three replications and two treatment factors, namely the dose of compost sludge and NPK fertilizer. The results showed that the application of sludge compost at a
\end{abstract}

dose of $15 \mathrm{t} / \mathrm{ha}$ and NPK fertilizer at a dose of $450 \mathrm{~kg} / \mathrm{ha}$ was able to increase the growth and yield of spring maize. While the interaction between the treatment of sludge compost and NPK fertilizer was only able to affect the height of spring maize with the best treatment interaction of $15 \mathrm{t} / \mathrm{ha}$ of sludge compost with $450 \mathrm{~kg} / \mathrm{ha}$ of NPK fertilizer.

Index Terms- Cob, compost, NPK, sludge

\section{INTRODUCTION}

$\mathrm{M}$ aize has long been used as a food ingredient in human life. In addition to food, maize can also be used for animal feed and industrial raw materials. The most popular type of corn is spring maize. Spring maize is maize cobs that are harvested at a young stage as a vegetable ingredient[1].

At first, consumers of spring maize were limited to certain circles, especially people in big cities. Today's spring maize trade is increasingly widespread, both between regions and between countries. People love spring maize because it tastes good, is highly nutritious, and has medicinal properties. Therefore, spring maize cultivation by initiative and commercial with an agribusiness pattern has bright prospects[1].

Abdoellah[2] reported that with increasing concern about the adverse effects on health due to contamination of artificial fertilizers, now the use of organic materials has begun to be increased, as well as reducing artificial (inorganic) fertilizers. This can serve to improve the physical and chemical properties of the soil (as a soil conditioner). Organic matter also helps provide the nutrients plants need even in small amounts. Good soil physical properties will cause the absorption of soil nutrients by plants to be easier and smoother.

In general, waste from palm oil consists of three forms, namely solid, liquid, and gas. Palm oil solid waste is grouped into two, namely those from processing and those from liquid waste processing[3]. Commercial use of sludge is recommended as a substitute for inorganic fertilizers and saves costs per hectare. Sludge compost has the potential as a soil buffer that can improve soil physical properties, such as stimulating better soil aggregation[4].

The results of the research by Tania et al.[5] showed that the application of sludge can improve soil chemical properties such as $\mathrm{pH}$, C-Organic, total N, available P, Ca-dd, Mg-dd, and K-dd. Judging from its nutritional content, sludge can be used as a fertilizer because palm oil waste is a good source of nutrients. The use of palm oil waste as additional fertilizer provides advantages in plant appearance and soil physico-chemical properties.

The use of NPK fertilizer in addition to providing benefits in terms of reducing the cost of sowing and distributing nutrients more evenly and balanced nutrient combinations, this fertilizer is also easy to apply and easy to get in the market. Each nutrient in NPK fertilizer has an important role for plant growth. Nitrogen stimulates the growth of leaves and stems, phosphorus stimulates plant growth so that leaves, flowers and fruit do not fall, and as a source of strength for plants to deal with drought and disease[6].

Based on this, this study aims to determine the effect of compost sludge and NPK fertilizer on the growth and yield of baby corn. 


\section{RESEARCH METHODS}

The research was carried out at the Agronomic Research Area, Faculty of Agriculture, Universitas Islam Sumatera Utara, Gedung Johor, Medan, North Sumatra with an altitude of $\pm 25 \mathrm{~m}$ above sea level.

The research method used a factorial randomized block design with three replications and two treatment factors. The first factor is: Dosage of solid palm oil waste compost (Sludge) (S) which consists of 4 levels, namely: $0 \mathrm{t} / \mathrm{ha}$ (S0), $5 \mathrm{t} / \mathrm{ha}$ (S1), $10 \mathrm{t} / \mathrm{ha}$ (S2), and $15 \mathrm{t}$ /ha (S3). The second factor is: Dosage of NPK fertilizer (P) which consists of 4 levels, namely: $0 \mathrm{~kg} / \mathrm{ha}(\mathrm{P} 0), 150 \mathrm{~kg} / \mathrm{ha}(\mathrm{P} 1), 300$ $\mathrm{kg} / \mathrm{ha}(\mathrm{P} 2)$, and $450 \mathrm{~kg} / \mathrm{ha}(\mathrm{P} 3)$.

Prior to the study, composting of solid palm waste (sludge) was first carried out. The results of the analysis of the nutrient content of the sludge compost, namely: $31.82 \%$ C-organic, $3.04 \% \mathrm{~N}, 6.85 \% \mathrm{P} 2 \mathrm{O} 5,0.67 \% \mathrm{~K} 2 \mathrm{O}$, and $68.93 \%$ water content with a $\mathrm{C} / \mathrm{N}$ ratio of 10.47 .

The experimental land was made in the form of plots measuring $2 \mathrm{~m}$ x $2 \mathrm{~m}$ with a height of approximately $30 \mathrm{~cm}$. Sludge compost was given one week before planting with the appropriate dose of treatment. Sludge compost was given by mixing the topsoil with compost, then spreading it evenly in the experimental plot. Meanwhile, NPK fertilizer is given one week after planting by placing it beside the plant as deep as 5-10 cm, then covering it with soil. The planting of baby corn was carried out individually with a depth of $3 \mathrm{~cm}$ and each planting hole was filled with 2 seeds with a spacing of $50 \mathrm{~cm} \times 20 \mathrm{c}$

Observational data that has been obtained during the study were processed according to the research method used. If there is a significant difference, it is continued with Duncan's test at the 5\% level. Data processing was carried out using Minitab 19 software.

\section{RESULTS OR FINDING}

Based on analysis of variance, it showed that the utilization of sludge compost and NPK fertilizer had a significant effect on the growth and yield of spring maize.

Table 1: Plant height (cm) spring maize with compost sludge and NPK fertilizer at 6 weeks after planting (WAP)

\begin{tabular}{|c|c|c|c|c|c|}
\hline \multirow{2}{*}{ Treatment } & \multicolumn{4}{|c|}{ Sludge Compost (t/ha) (S) } & \multirow{2}{*}{ Average $(\mathrm{P})$} \\
\hline & 0 & 5 & 10 & 15 & \\
\hline \multicolumn{6}{|c|}{ NPK fertilizer $(\mathrm{kg} / \mathrm{ha})(\mathrm{P})$} \\
\hline 0 & $173.50 \mathrm{~h}$ & $183.50 \mathrm{~g}$ & $201.73 \mathrm{~cd}$ & $199.73 \mathrm{~d}$ & $189.62 \mathrm{~d}$ \\
\hline 150 & $176.20 \mathrm{~h}$ & $187.40 \mathrm{f}$ & $202.20 \mathrm{bcd}$ & $201.73 \mathrm{~cd}$ & $191.88 \mathrm{c}$ \\
\hline 300 & $187.87 \mathrm{f}$ & $193.63 \mathrm{e}$ & 204.97 bc & $205.73 \mathrm{bc}$ & $198.05 \mathrm{~b}$ \\
\hline 450 & $198.73 \mathrm{~d}$ & $199.87 \mathrm{~d}$ & $206.30 \mathrm{~b}$ & $212.87 \mathrm{a}$ & $204.44 \mathrm{a}$ \\
\hline Average (S) & $184.08 \mathrm{c}$ & $191.10 \mathrm{~b}$ & $203.80 \mathrm{a}$ & $205.02 \mathrm{a}$ & \\
\hline
\end{tabular}

Table 1 shows that there is a treatment interaction between sludge compost and NPK fertilizer which has a significant effect on spring maize plant height. The highest plants were obtained at the interaction of treatment of $15 \mathrm{t} / \mathrm{ha}$ sludge compost with $450 \mathrm{~kg} / \mathrm{ha} \mathrm{NPK}$ fertilizer, which was $212.87 \mathrm{~cm}$ and the lowest was in the interaction treatment without sludge compost and without NPK fertilizer, which was $173.50 \mathrm{~cm}$. The increase in plant height occurred and was able to run normally because the element $\mathrm{N}$ was closely correlated with the development of active meristem tissue from sludge compost and NPK fertilizer, thus determining plant height growth. According to Sutanto[7], macro nutrients such as N, P and K can be obtained from the addition of organic and inorganic materials into the soil. In line with the research results of Pradipta et al.[8] which shows that the combination of compost sludge and inorganic fertilizer according to the recommended dose can provide $\mathrm{N}, \mathrm{P}$, and $\mathrm{K}$ nutrients in the soil.

Table 2 shows that the sludge compost and NPK fertilizer independently significantly affected the stem diameter of spring maize. However, the interaction did not significantly affect the stem diameter of spring maize.

Utilization of sludge compost significantly affected the stem diameter of spring maize at the age of 6 WAP. The largest stem diameter was obtained in the treatment of $15 \mathrm{t} / \mathrm{ha}$ compost sludge, which was $1.98 \mathrm{~cm}$, and the smallest stem diameter in the treatment without sludge compost, which was $1.92 \mathrm{~cm}$. This is due to the provision of compost sludge containing nutrients that can be used by plants to grow optimally. Jenny and Sawadji[9] stated that sludge can increase soil fertility and a number of soil chemical activities. This is in line with the results of Budianta's[10] research which showed that the provision of palm oil solid waste was able to increase the nutrient content needed by plants.

The application of NPK fertilizer significantly affected the stem diameter of spring maize with the largest diameter obtained in the 
treatment of $450 \mathrm{~kg} / \mathrm{ha}$ of NPK fertilizer, which is $1.99 \mathrm{~cm}$ and the smallest diameter obtained in the treatment without NPK fertilizer, which is $1.92 \mathrm{~cm}$. This situation means that by applying NPK fertilizer as much as $450 \mathrm{~kg} / \mathrm{ha}$ can increase the diameter of spring maize stems compared to the application of lower doses of NPK fertilizer. This is because NPK fertilizer is a compound fertilizer that contains macro nutrients which are essential for plants which include N, P, and K. This is what causes NPK fertilizers up to $450 \mathrm{~kg} / \mathrm{ha}$ to increase the growth of spring maize stem diameter. According to Damanik et al.[11], $\mathrm{N}$ and $\mathrm{K}$ in plants are very important for the formation of proteins, leaves and various other organic compounds. $\mathrm{N}$ is the nutrient that is most needed by plants and has a very important role for plant growth, while the plant's need for $\mathrm{K}$ is quite high and has a lot to do with plant growth and helps erect stems. Furthermore, Yandianto[12] stated that $\mathrm{P}$ is useful for plants, especially for growth and development, for example for the growth of plant seedlings, branches, shoots and plant stems.

Table 2: Stem diameter (cm) spring maize with compost sludge and NPK fertilizer at 6 weeks after planting (WAP)

\begin{tabular}{|c|c|c|c|c|c|}
\hline \multirow{2}{*}{ Treatment } & \multicolumn{4}{|c|}{ Sludge Compost (t/ha) (S) } & \multirow{2}{*}{ Average $(\mathrm{P})$} \\
\hline & 0 & 5 & 10 & 15 & \\
\hline \multicolumn{6}{|c|}{ NPK Fertilizer (kg/ha) (P) } \\
\hline 0 & 1.88 & 1.93 & 1.90 & 1.97 & $1.92 \mathrm{c}$ \\
\hline 150 & 1.93 & 1.93 & 1.95 & 1.97 & $1.94 \mathrm{bc}$ \\
\hline 300 & 1.94 & 1.95 & 1.98 & 1.99 & $1.96 \mathrm{~b}$ \\
\hline 450 & 1.94 & 1.99 & 2.02 & 2.00 & $1.99 \mathrm{a}$ \\
\hline Average (S) & $1.92 \mathrm{~b}$ & $1.95 \mathrm{a}$ & $1.96 \mathrm{a}$ & $1.98 \mathrm{a}$ & \\
\hline
\end{tabular}

The provision of compost sludge and the interaction between the two treatments had no significant effect on the number of spring maize cobs, but the application of NPK fertilizer had a significant effect on the number of spring maize cobs (Table 3).

Table 3: Number of spring maize cobs (cob) with compost sludge and NPK fertilizer at the age of 6 weeks after planting (WAP)

\begin{tabular}{lccccc}
\hline \multirow{2}{*}{ Treatment } & \multicolumn{2}{c}{ Sludge Compost (t/ha) (S) } & \multirow{2}{*}{ Average (P) } \\
\cline { 2 - 4 } NPK Fertilizer (kg/ha) (P) & 0 & 5 & 10 & 15 & $29.22 \mathrm{~b}$ \\
0 & 28.67 & 30.67 & 29.67 & 29.67 & $29.67 \mathrm{~b}$ \\
150 & 29.33 & 28.67 & 29.67 & 31.00 & $30.83 \mathrm{a}$ \\
300 & 30.67 & 30.33 & 31.00 & 31.33 & $31.00 \mathrm{a}$ \\
450 & 30.33 & 31.00 & 31.00 & 30.92 & \\
\hline Average (S) & 30.00 & 30.17 & 30.33 & \\
\hline
\end{tabular}

Note: The numbers in the same column and row followed by different notations show significant differences at the $5 \%$ level based on Duncan's test.

Average: The number in each mean followed by a different notation shows a significant difference at the $5 \%$ level based on Duncan's test.

Table 3 shows that the utilization of sludge compost has no significant effect on the number of spring maize cobs with the highest number of cobs obtained in the treatment of $15 \mathrm{t} / \mathrm{ha}$ of sludge compost, which is 30.92 cobs, and the lowest in the treatment without sludge compost, which is 30.00 cobs

The application of NPK fertilizer had a significant effect on the number of spring maize cobs (Table 3). The highest number of cobs was obtained in the treatment of $450 \mathrm{~kg} / \mathrm{ha}$ NPK, which was 31.00 cobs and the lowest in the treatment without NPK fertilizer, which was 29.22 cobs. The dose of $450 \mathrm{~kg} / \mathrm{ha}$ of NPK gave higher spring maize yields than the dose of $150 \mathrm{~kg} / \mathrm{ha}$ of NPK. This is because the provision of NPK fertilizer can increase the availability and uptake of N, P and K nutrients by spring maize. Plants will thrive if the nutrients needed are available and available in a form that can be absorbed by plants. Furthermore, Suratmini[13] stated that the application of NPK fertilizer that was less than optimal had low yields when compared to the application of sufficient doses. This is in line with the results of research by Sathish et al.,[14] which showed that NPK fertilization with the optimum dose in Kathalagere was able to increase maize yields and NPK nutrient uptake.

The application of sludge compost and the application of NPK fertilizer had a significant effect on the weight of cobs per plot of spring maize, but the interaction between the two treatments had no significant effect on the weight of cobs per plot of spring maize (Table 4). 
Table 4: The weight of cobs per plot (kg) of spring maize with the addition of compost sludge and fertilizer

\begin{tabular}{|c|c|c|c|c|c|}
\hline \multirow{2}{*}{ Treatment } & \multicolumn{4}{|c|}{ Sludge Compost (t/ha) (S) } & \multirow{2}{*}{ Average $(\mathrm{P})$} \\
\hline & 0 & 5 & 10 & 15 & \\
\hline \multicolumn{6}{|c|}{ NPK Fertilizer (kg/ha) (P) } \\
\hline 0 & 2.94 & 3.06 & 2.97 & 2.97 & $2.98 \mathrm{~b}$ \\
\hline 150 & 2.94 & 2.88 & 2.94 & 3.13 & $2.97 \mathrm{~b}$ \\
\hline 300 & 3.06 & 3.04 & 3.11 & 3.13 & $3.08 \mathrm{a}$ \\
\hline 450 & 3.04 & 3.11 & 3.11 & 3.17 & $3.11 \mathrm{a}$ \\
\hline Average $(\mathrm{S})$ & $3.00 \mathrm{~b}$ & $3.02 \mathrm{~b}$ & $3.03 \mathrm{ab}$ & $3.10 \mathrm{a}$ & \\
\hline
\end{tabular}

Note: The numbers in the same column and row followed by different notations show significant differences at the 5\% level based on Duncan's test.

Average: The number in each mean followed by a different notation shows a significant difference at the 5\% level based on Duncan's test

Table 4 shows that the utilization of sludge compost has a significant effect on the weight of cobs per plot. The heaviest cob weight per plot was obtained in the treatment of $15 \mathrm{t} /$ ha of sludge compost, which was $3.10 \mathrm{~kg}$ and the lowest was in the treatment without sludge compost, which was $3.00 \mathrm{~kg}$. This is due to the availability of $\mathrm{N}$ nutrients which are mostly transferred in the generative phase so that it can stimulate the formation of better maize cobs[15]. This is in line with the results of research by Ainurrahmi[16] which showed that the application of organic matter resulted in changes in the chemical properties of the soil and improved the growth and production of maize better than without the application of organic matter.

Table 4 also shows that the application of NPK fertilizer had a significant effect on the weight of cobs per plot. The heaviest cob weight per plot was obtained in the $450 \mathrm{~kg} / \mathrm{ha}$ NPK treatment, which was $3.11 \mathrm{~kg}$ and the lowest in the treatment without NPK fertilizer, which was $3.00 \mathrm{~kg}$. The results showed that the larger the dose of NPK fertilizer applied, the heavier the weight of the cobs per plot produced. This is due to the increasing number of available nutrients resulting in a better rate of photosynthesis during growth which results in larger and heavier cobs. According to Rahni[17], the increase in crop yields is related to the amount of photosynthate translocation into seeds and the better the plant root system to be able to absorb nutrients from the soil. Translocation of photosynthate which is quite large to the reproductive organs causes cob formation and seed filling to take place well and the seeds are formed with a larger size. Furthermore, Yulisma[18] stated that the high or low value of the weight of the corn cobs produced is determined by the rate of photosynthesis which is the accumulation of photosynthate during growth.

The application of sludge compost and the application of NPK fertilizer had a significant effect on cob weight without protective leaf per plot, but the interaction between the two treatments had no significant effect on cob weight without protective leaf per plot (Table 5).

Table 5 shows that the application of sludge compost has a significant effect on the weight of the cob without protective leaf per plot. The heaviest weight of cob without protective leaf per plot was obtained in the treatment of $15 \mathrm{t} / \mathrm{ha}$ of sludge compost, which was 2.01 $\mathrm{kg}$ and the lowest was in the treatment without sludge compost, which was $1.93 \mathrm{~kg}$, which was $3.00 \mathrm{~kg}$. This is due to the maximum release of nutrients sourced from sludge compost so that nutrients can be obtained by plant roots and used for the formation of cobs. According to Jenny and Suwadji[9]; Pradipta et al.[8], sludge compost that has been applied to the soil can improve soil fertility, increase water absorption and become an energy source for soil microbes. In line with the research results of Darmawati et al.[19] which showed that fertilization using sludge at a dose of $34 \mathrm{t} /$ ha could have a significant effect on plant yield variables which included length of cob, diameter of cob, weight of cob, and weight of cob per plot.

Table 5: Weight of cob without protective leaf per plot $(\mathrm{kg})$ spring maize with compost sludge and NPK fertilizer at the age of 6 weeks after planting (WAP)

\begin{tabular}{|c|c|c|c|c|c|}
\hline \multirow{2}{*}{ Treatment } & \multicolumn{4}{|c|}{ Sludge Compost (t/ha) (S) } & \multirow{2}{*}{ Average $(\mathrm{P})$} \\
\hline & 0 & 5 & 10 & 15 & \\
\hline \multicolumn{6}{|c|}{ NPK Fertilizer (kg/ha) (P) } \\
\hline 0 & 1.85 & 1.99 & 1.93 & 1.93 & $1.92 \mathrm{~b}$ \\
\hline 150 & 1.91 & 1.86 & 1.93 & 2.02 & $1.93 \mathrm{~b}$ \\
\hline 300 & 1.99 & 1.97 & 2.02 & 2.04 & $2.00 \mathrm{a}$ \\
\hline 450 & 1.97 & 2.02 & 2.02 & 2.06 & $2.02 \mathrm{a}$ \\
\hline Average $(\mathrm{S})$ & $1.93 \mathrm{~b}$ & $1.96 \mathrm{ab}$ & $1.97 \mathrm{ab}$ & $2.01 \mathrm{a}$ & \\
\hline
\end{tabular}

Note: The numbers in the same column and row followed by different notations show significant differences at the $5 \%$ level based on Duncan's test. Average: The number in each mean followed by a different notation shows a significant difference at the $5 \%$ level based on Duncan's test.

Table 5 also shows that the application of NPK fertilizer had a significant effect on cob weight without protective leaf per plot. The heaviest cob weight without protective leaf per plot was obtained in the $450 \mathrm{~kg} / \mathrm{ha} \mathrm{NPK}$ treatment, which was $2.02 \mathrm{~kg}$ and the lowest in the treatment without NPK fertilizer, which was $1.92 \mathrm{~kg}$. One of the elements that play a role in fruit development is the element N, if these elements are met then the process of development of corn fruit becomes optimal and ripe on time. This is in line with the 
results of Rina's research[20] which shows that if the $\mathrm{N}$ element is sufficient, the fruit development will be perfect and ripe on time, and if the $\mathrm{N}$ element is not sufficient then the fruit development will be imperfect and often ripen prematurely

\section{CONCLUSION}

The application of sludge compost at a dose of 15 t/ha was able to increase plant height, stem diameter, weight of cobs per plot, and weight of cobs without protective leaf per plot of spring maize compared to without sludge composting. Likewise, the application of NPK fertilizer at a dose of $450 \mathrm{~kg} / \mathrm{ha}$ was able to increase plant height, stem diameter, number of cobs, weight of cobs per plot, and weight of cobs without protective leaf per plot of spring maize compared to without application of NPK fertilizer. While the interaction between the treatment of sludge compost and NPK fertilizer was only able to affect the height of spring maize with the best treatment interaction of $15 \mathrm{t} / \mathrm{ha}$ of sludge compost with $450 \mathrm{~kg} / \mathrm{ha}$ of NPK fertilizer.

\section{REFERENCES}

[1] R. Rukmana, Budidaya Baby Corn. Yogyakarta: Kanisius, 1997.

[2] Abdoellah. (2000). Pemanfaatan Limbah Kelapa Sawit [Online]. Available: www.wikipedia.com.

[3] B. Utomo, dan E. Widjaja, Limbah Padat Pengolahan Minyak Sawit Sebagai Sumber Nutrisi Ternak. Palangkaraya: Balai Pengkajian Teknologi Pertanian Kalimantan Tengah, 2004.

[4] F. I. Stevenson, Humus Chemistry Genesis. Composition Reaction. New York: Jhon Willey and Sons, Inc. 1994.

[5] N. Tania, et al., "Pengaruh pemberian pupuk hayati terhadap pertumbuhan dan hasil jagung semi pada tanah podsolik merah kuning', Jurnal Sains Mahasiswa Pertanian, vol. 1, pp. 10-15, 2012.

[6] P. Lingga, dan Martono, Petunjuk Pengguanaan Pupuk, Jakarta: Penebar Swadaya, 2004.

[7] R. Sutanto, Penerapan Pertanian Organik, Yogyakarta: Kanisius, 2002.

[8] M. Pradipta, et al., "Kombinasi pemberian limbah padat (sludge) pabrik kelapa sawit dan pupuk N, P dan K pada tanaman jagung manis (Zea mays Var saccharata Sturt)', Jurnal Online Mahasiswa Fakultas Pertanian Universitas Riau, vol. 4, pp. 1-11, 2017.

[9] M. U. Jenny, dan E. Suwadji. Pemanfaatan Limbah Minyak Sawit (Sludge) sebagai Pupuk Tanaman dan Media Jamur Kayu, 1999.

[10] D. Budianta. "Evaluasi pemanfaatan limbah cair kelapa sawit terhadap ketersediaan hara dan produksi tandan buah segar kelapa sawit", J. Tanah Trop. vol. 10, pp. 27-32, 2004

[11] M. M. B. Damanik, et al., Kesuburan Tanah dan Pemupukan, Medan: USU Press, 2011, pp. 262.

[12] Yandianto, Bercocok Tanam Padi, Banfung: M2S, 2003.

[13] P. Suratmini, "Kombinasi pemupukan urea dan pupuk organik pada jagung manis di lahan kering", Penelitian Pertanian Tanaman Pangan, vol.. $28,83-88,2009$.

[14] A. G. Sathish et al., "Long term effect of integrated and inorganic fertilizers on productivity, soil fertility and uptake of nutrients in rice and maize cropping system', I J S N, vol. 2, pp. 84-88, 2011.

[15] N. Nurhayati, "Pertumbuhan dan hasil jagung manis pada berbagai waktu aplikasi bokashi limbah kulit buah kakao dan pupuk anorganik", J. Agroland, vol 13, pp. 256-259, 2006.

[16] R. Ainurrahmi, Pengaruh pemanfaatan limbah tahu terhadap serapan N, P dan K serta pertumbuhan tanaman jagung [Skripsi], Bogor: Institut Pertanian Bogor, 2008.

[17] N. M. Rahni, "Efek fitohormon PGPR terhadap pertumbuhan tanaman jagung (Zea mays)", J Agribisnis Pengembangan Wilayah, vol 3, pp. $27-35,2012$.

[18] Yulisma, "Pertumbuhan dan hasil beberapa varietas jagung pada berbagai jarak tanam", Penelitian Pertanian Tanaman Pangan, vol 30, pp. 196-203, 2011.

[19] J. S. Darmawati, et al., "Pengaruh pemberian limbah padat (sludge) kelapa sawit dan pupuk organik cair terhadap pertumbuhan dan produksi tanaman jagung manis (Zea mays saccharata)", Agrium, vol 19, pp.59-67, 2014.

[20] Rina, Pertumbuhan dan Hasil Tanaman Jagung (Zea mays L.) Yang Ditumpangsarikan Dengan Kedelai (Glycine max L.), Padang: Fakultas Pertanian Jurusan Agroteknologi Universitas Tamansiswa, 2015.

\section{AUTHORS}

First Author - Mindalisma, Department of Agrotechnology, Faculty of Agriculture, Universitas Islam Sumatera Utara, Jalan Karya Wisata Gedung Johor, Medan 20144, Indonesia, Email: mindalisma@fp.uisu.ac.id.

Second Author - Yenni Asbur, Department of Agrotechnology, Faculty of Agriculture, Universitas Islam Sumatera Utara, Jalan Karya Wisata Gedung Johor, Medan 20144, Indonesia, Email: yenni.asbur@ fp.uisu.ac.id.

Third Author - Chairani Siregar, Department of Agrotechnology, Faculty of Agriculture, Universitas Islam Sumatera Utara, Jalan Karya Wisata Gedung Johor, Medan 20144, Indonesia, Email: chairanichairani@fp.uisu.ac.id.

Fourth Author - Ratna Mauli Lubis, Department of Agrotechnology, Faculty of Agriculture, Universitas Islam Sumatera Utara, Jalan Karya Wisata Gedung Johor, Medan 20144, Indonesia, Email: ratnalili@ fp.uisu.ac.id.

Fifth Author - Diapari Siregar, Department of Agrotechnology, Faculty of Agriculture, Universitas Islam Sumatera Utara, Jalan Karya Wisata Gedung Johor, Medan 20144, Indonesia, Email: diaparisiregar@ fp.uisu.ac.id.

Sixth Author - Yayuk Purwaningrum, Department of Agrotechnology, Faculty of Agriculture, Universitas Islam Sumatera Utara, Jalan Karya Wisata Gedung Johor, Medan 20144, Indonesia, Email: yayuk.purwaningrum@ @ fp.uisu.ac.id.

Seventh Author - Rahmi Dwi Handayani Rambe, Department of Agrotechnology, Faculty of Agriculture, Universitas Islam Sumatera Utara, Jalan Karya Wisata Gedung Johor, Medan 20144, Indonesia, Email: rahmi.dwihandayani@fp.uisu.ac.id. 
ISSN 2250-3153

Correspondence Author - Mindalisma, mindalisma@fp.uisu.ac.id, yenniasbur@gmail.com. 